\title{
PORTRET ANTROPOLOGICZNY RDZENNYCH MIESZKAŃCÓW POGRANICZA POLSKO-NIEMIECKIEGO URODZONYCH PRZED 1945 ROKIEM
}

W artykule przedstawiamy wyniki badań terenowych przeprowadzonych wśród rdzennych mieszkańców województwa lubuskiego urodzonych przed 1945 rokiem w państwie niemieckim'. Od 1945 roku ludność tutejsza zaczęła masowo opuszczać ten teren w wyniku ewakuacji, ucieczki, dzikich wypędzeń, wysiedleń, akcji łączenia rodzin (Wysiedlenia 2008: 166-201) i trwającej do dzisiaj emigracji ekonomicznej. Osoby, z którymi przeprowadziłyśmy wywiady, pozostały w Polsce z różnych powodów:

1. pozwolono im zostać ze względu na polskie pochodzenie rodziny (przede wszystkim we wsiach tworzących enklawy polskiej mniejszości przy wytyczonej w 1919 granicy polsko-niemieckiej: Nowe Kramsko, Dąbrówka Wielkopolska, Pszczew i okoliczne wsie). Do tej kategorii można też zaliczyć rodziny, których przodkowie przybyli w celu znalezienia pracy w okresie zaborów i międzywojnia;

Dr Magdalena POKRZYŃSKA jest adiunktem w Instytucie Socjologii Uniwersytetu Zielonogórskiego. mpokrz@wp.pl

Dr hab. Anna ZIELIŃSKA jest profesorem w Instytucie Slawistyki PAN w Warszawie i w Państwowej Wyższej Szkole Zawodowej w Gorzowie WIkp. azielinska@ispan.waw.pl

1 We wcześniejszym artykule omówiłyśmy losy 4 osób z badanej kategorii i wstępne ustalenia metodologiczne (Pokrzyńska, Zielińska 2010). 
2. zostali zawróceni w trakcie ucieczki przed frontem w 1945 roku lub sami decydowali się na powrót, a nawet ucieczkę z transportu podczas przymusowych wysiedleń2;

3. zwlekali z ucieczką, uniknęli wysiedlenia, a potem nie chcieli bądź nie mogli wyjechać3.

Rozmówcy to ostatni świadkowie historii, których doświadczenia zaczynają się na tej ziemi już w czasach przedwojennych. Odróżnia to ich od innych mieszkańców regionu, którzy są przybyszami, i stanowi o ich szczególnej pozycji z perspektywy poczucia zakorzenienia, rozumienia małej ojczyzny, tożsamości regionalnej, pojmowania historii4.

Badania przeprowadzityśmy w latach 2009-2011 w 17 miejscowościach województwa lubuskiego. Dysponujemy wywiadami z 28 osobami, w tym 5 wywiadów przeprowadzili studenci socjologii Uniwersytetu Zielonogórskiego ${ }^{5}$.

\section{POGRANICZE POLSKO-NIEMIECKIE}

Przyjmuje się zazwyczaj, że pogranicze polsko-niemieckie obejmuje szeroki pas po obu stronach granicy państwowej na Odrze i Nysie, choć jego zasięg terytorialny i charakter są przedmiotem dyskusji (Gołdyka 2003: 290; Kurcz 1999: 219-220; Mucha 2001: 72-73). Terenem badań uczyniłyśmy województwo lubuskie, stanowiące fragment współczesnego i historycznego pogranicza polsko-niemieckiego. Świadomość, że jest to terytorium pograniczne, kształtujące się w toku dziejów, wykazują również nasi rozmówcy, którzy w swoich narracjach nawiązywali do okresów wcześniejszych - międzywojennych i sprzed I wojny światowej - z nich wywodząc tożsamość rodziny i ducha miejsca, którego są mieszkańcami. Motyw granicy często pojawia się w opowieściach o losach rodzin. Granica wytyczona w 1919 roku podzieliła rodziny: część krewnych znalazła się w Polsce, a część w Niemczech. Granicę w okresie międzywojennym często przekraczali dziadkowie i rodzice, poszukując pracy i lepszych warunków życia w Niemczech. Granica ustalona w 1945 roku stała się kordonem, za którym znaleźli się ich krewni, często najbliżsi: rodzice, rodzeństwo, nawet dziecí. Teraz do Niemiec emigrują lub wyjeżdżają sezonowo do pracy ich wnuki. Rozmówcy postrzegają analogię z losami ich dziadków, którzy również "jechali za chlebem".

Przemiany pogranicza polsko-niemieckiego opisują historycy. Zauważają oni wpływ decyzji politycznych na jego zasięg, a także działalności ekonomicznej i migracji na relacje społeczne i kulturę (np. Benyskiewicz 1994: 11-26). Mianem ziemi lubuskiej określa się

2 Por. relację: „Moi rodzice mieszkali w Starym Kisielinie. (...) Jak one były wysiedlone później, to oni wpierw tak wysiedlili, Ruski wysiedlili Stary Kisielin i Czarne. I moja mama, tu jak się idzie do Wieży Brandenburskiej do góry, to mama powiedziała, że ona nie idzie i ucieka z tego całego transportu. I zaczynali za nią strzelać. No i ona uciekła, (...) i przez to ona została tu. A za parę dni przyszła znajoma i mówi: Ty uważaj, aby ciebie nie wysiedlili, bo twoja mama się wróciła, siedzi u was w piwnicy. No i przez to ja się tu została" (EM Nowy Kisielin).

3 Są to indywidualne historie. O strategii postępowania władz wobec rdzennych mieszkańców rozmówczyni mówi: "Bo oni robili tak: Ten co chciał zostać, to tego wysiedlili, a ten co chciał nie zostać, tego właśnie zatrzymali" (EM Nowy Kisielin).

4 Silna jest świadomość bycia „ostatnim”. Jeden z rozmówców przywołał podczas wywiadu słowa swojego znajomego, który powiedział mu: „Ty musisz dbać o swoje zdrowie, bo ty jesteś ostatni, który wie o tym coś". Inny przedstawił się "Jestem ostatnim Landsberczykiem” [Landsberg - przedwojenna nazwa Gorzowa WIkp. - przyp. aut.].

5 Uczestnicy seminarium dr Magdaleny Pokrzyńskiej: Wiktoria Czepułkowska, Elżbieta Janowska, Monika Kowalińska, Magdalena Kozłowska, Martyna Netzel.

6 Rozmówczyni z Siecioborzyc na wiele lat straciła kontakt z córką. Dziewięcioletnia dziewczynka wyjechała do Niemiec z babcią i dziadkiem w latach powojennych. Jej rodzicom nie udało się dołączyć z powodu problemów z uzyskaniem paszportu. Rodzina była rozłączona do lat 70. 
dziś obszar, gdzie przechodziły (mające płynny charakter i często się zmieniające) granice takich regionów historycznych, jak: Nowa Marchia (czyli wschodnia część Brandenburgii), Dolny Śląsk, Zachodnia Wielkopolska, Dolne Łużyce oraz Pomorze (Rutowska, Tomczak 2003: 7). Dawne podziały regionalne okazują się aktualne. Dziś są przywoływane w działaniach zbiorowych skierowanych na odkrywanie i kształtowanie małych ojczyzn. Przykładem jest stosowanie nazwy z rodowodem niemieckim „ziemia torzymska” (niem. Sternberger Land), obejmującej dzisiejsze powiaty sulęciński i słubicki, oraz powstanie Stowarzyszenia Przyjaciół Ziemi Torzymskiej (Czarnuch 2004). Nawiązaniem do przeszłości jest nazwa programu naukowego "Nowa Marchia - prowincja zapomniana - wspólne korzenie" realizowanego w Bibliotece Miejskiej w Gorzowie WIkp. Odwołania i komentarze dotyczące dawnych i obecnych podziałów administracyjnych, centrów regionalnych i kontaktów pomiędzy społecznościami lokalnymi, nazewnictwa regionalnego pojawiały się też w przeprowadzonych przez nas wywiadach.

$\mathrm{Na}$ obecne oblicze tego regionu w sposób istotny wpłynęła wymiana ludności po II wojnie światowej. Wśród osadników należących do różnych grup społecznych, najliczniej reprezentowane były kategorie osób przymusowo wysiedlonych z byłych Kresów oraz dobrowolnych przesiedleńców z Polski centralnej i Poznańskiego. Po 1947 roku pojawili się tu także przedstawiciele mniejszości ukraińskiej i Łemków. Kulturę powojennych osadników cechowało duże zróżnicowanie wewnętrzne (poszczególne kategorie ludności reprezentowały różne kultury regionalne i etniczne, por. J. Burszta 1967; Kołodziejska 2006: 147-148). Ziemie te stanowiły obszar, gdzie dokonywały się bardziej lub mniej spontaniczne procesy uwspólniania kultury, zwane przez powojennych badaczy mianem integracji społeczno-kulturowej, akomodacji, adaptacji, autochtonizacji (m.in. J. Burszta 1971, 1974a, 1974b; Dulczewski 1961, 1967, 1971).

Posługując się kategoryzacją uwzględniającą kryterium miejsca pochodzenia, rozmówców należałoby zakwalifikować do ludności rodzimej. W okresie powojennym na jej określenie stosowano nazwę „autochton”. Pojęcie to przedstawił szerzej Zygmunt Dulczewski: „Najczęściej, gdy używa się tej nazwy ma się na myśli mieszkańców Ziem Zachodnich, którzy pozostali na miejscu w chwili rozpoczęcia wielkich ruchów migracyjnych w 1945 r. w związku z przegraniem przez Niemcy wojny i przyłączeniem tych ziem do Polski" (1961: 13). Autor ten zwraca uwagę, iż z tym pojęciem łączą się pewne cechy etnograficzne, demograficzne, antropologiczne i - nade wszystko - socjologiczne. Ostatnia z wymienionych perspektyw wiąże się ze społeczną funkcją przypisywaną po wojnie tej kategorii mieszkańców Polski zachodniej, polegającą na „dawaniu świadectwa o prawach Polski do Ziem Zachodnich oraz (...) umacnianiu poczucia swojskości w stosunku do tych ziem ludności polskiej (...)” (Dulczewski 1961: 14). Wiesław Sauter zaś mówi: „Ludność ta była niezaprzeczalnym dokumentem polskości odzyskanych ziem i najcenniejszym argumentem na arenie międzynarodowej w trwającej wówczas wymianie zdań na temat praw Polski do tych ziem" (Ćwiklińska 1995: 18). Zgodnie z powojennym nazewnictwem do kategorii „autochtonów” nie należeli przedstawiciele „poprzednio tu zamieszkałej ludności niemieckiej, która w r. 1945 wybrała ucieczkę bądź przesiedlenie na zachód" (Dulczewski 1961: 13).

Kultura tzw. ludności autochtonicznej stanowiła przedmiot zainteresowań badaczy i regionalistów, obiekt działań politycznych i zabiegów socjotechnicznych. Powojenne badania prowadzone przez archeologów, etnografów i historyków, jak też dialektologów koncentrowały się głównie na udokumentowaniu istniejącego dziedzictwa polskiego na inkorporowanych terenach oraz odnalezieniu artefaktów potwierdzających polskość tych 
ziem (tym samym uzasadniających prawo państwa polskiego do nich). Szczególnym obiektem badań na terenie obecnego województwa lubuskiego była kultura Polaków spod znaku rodła. Poszukiwano w niej m.in. źródła kultury regionalnej dla kształtowanego na tym terenie "regionu nowego typu” (Dulczewski 1961; tenże 1962). Jako, iż na terenach objętych po wojnie nazwą „ziemia lubuska” przedstawicieli należącej do kategorii ludności rodzimej było stosunkowo niewiele, co więcej nie stanowili oni raczej jednego zwartego kompleksu (poza Babimojszczyzną), pojawił się problem dziedzictwa, które można byłoby uznać za kulturę regionalną mającą nie tylko walor „tutejszości”, ale także pochodzenia z przeszłości (dając tym samym poczucie ciągłości). Ostatecznie posłużono się wzorami tradycyjnej kultury ludowej z zachodniej Wielkopolski. Strój z okręgu babimojsko-międzyrzeckiego określony został w „Atlasie polskich strojów ludowych” jako strój lubuski (Glapa 1956; Kutrzebianka 1950: 175-181), natomiast tzw. suita lubuska prezentowana przez powołany do życia w 1953 roku Zespół Pieśni i Tańca Ziemi Lubuskiej przedstawia folklor z okolic Dąbrówki Wielkopolskiej (Dulczewski 1967: 329-330; por. Dokowicz, Sidło, Nowak 1998: 26). Dzięki tym działaniom można było napisać, że „Przeszłość ludności rodzimej Ziemi Lubuskiej stała się częścią historii regionu lubuskiego, kartą w historii polskiej" (Koniusz 1978: 214).

W pierwszych powojennych dekadach opublikowane zostały liczne artykuły i monografie prezentujące wnioski z badań przeprowadzonych na inkorporowanych terenach (np. praca zbiorowa Ziemia Lubuska wydana w cyklu "Ziemie Staropolski" - Sczaniecki, Zajchowska 1950), nakręcone zostały filmy im poświęcone (np. Ziemia Lubuska z 1947 roku), pozyskano do zbiorów muzealnych zabytki dokumentujące kulture polskiej ludności autochtonicznej. W okresie tym nie prowadzono jednak badań nad problemami związanymi z kwestią tożsamości. Pewien wyjątek mogą stanowić prace Stanisława Ossowskiego na temat więzi regionalnej i ojczyzny, napisane na podstawie badań przeprowadzonych na Opolszczyźnie (1984: 75-134).

Lektura opracowań z pierwszych dekad powojennych nie daje pełnego obrazu rzeczywistości z tamtych lat, wydarzeń wchodzących w krąg osobistych doświadczeń życiowych mieszkańców tych ziem. Na ten fakt wpłynął bez wątpienia ówczesny klimat polityczny i społeczny. Dokonywała się wtedy akcja weryfikacji przynależności narodowej, wysiedlania ludności niemieckiej, "(re)polonizacji” krajobrazu kulturowego i rdzennych mieszkańców (np. kursy języka polskiego), co szerzej opisują dopiero współcześni badacze. Aktualne badania stanowią nowe spojrzenie na "dawnych autochtonów” i przedstawiają ich w innym, nieznanym (przemilczanym i nieopisywanym lub ocenzurowanym) wcześniej świetle (np. Nitschke 2006; Kościk 2005). Dowodzą, że wyjście poza ukutą w powojennej literaturze kategorię „autochtonów” pozwala dostrzec nowe problemy i zjawiska na pograniczu polsko-niemieckim. Tak się dzieje w przypadku badań prowadzonych nad aktualnymi problemami związanymi ze współpracą transgraniczną, otwarciem granic i kształtowaniem nowego - postmigracyjnego - społeczeństwa w Polsce zachodniej. Problematyka ludności rodzimej zeszła na plan dalszy. Być może, czując przesyt literaturą powojenną, uznano, że temat został wyczerpany.

Przeprowadzone przez nas wywiady antropologiczne dają nowy obraz rdzennych mieszkańców pogranicza polsko-niemieckiego. Porzucenie pojęciowej kategorii „autochtona” pozwolito na dostrzeżenie przedstawicieli ludności tutejszej spoza wąskiego kręgu Polaków spod znaku rodła. Rezygnacja z tego pojęcia wynika też ze świadomości jego wcześniejszego stosowania w celach politycznych (a co za tym idzie, zmiany pierwotnego neu-

\section{-....}

7 Obecna nazwa: Lubuski Zespół Pieśni i Tańca. 
tralnego znaczenia słowa „autochton”) oraz nacechowania emocjonalnego, które sprawiło, że było używane jako przezwisko:

"Nas tu wyzywali od Autochtonów" (JW Skwierzyna).

"Wyzywali nas tu i Germany, i Autochtoni" (WJ Nowe Kramsko).

"Autochton to takie, (...), że my za Niemca się mieli, to bardzo źle" (GM Nowe Kramsko); (por. Sauter 1961: 43).

Słowo „autochton” w języku naszych rozmówców ma różne znaczenia, np.:

1. jest synonimem etnonimu "Niemiec":

„- Przed chwilą wspominała Pani pojęcie autochtonów, czy czuje się pani autochtonką?

- Nie, teraz już nie, broń Boże! Byłam Niemką przez szesnaście lat i ile lat już jestem Polką.

Nie, to absolutnie autochtonką się nie czuję" (MŁ Zielona Góra);

2. oznacza osobę dwujęzyczną:

„- Autochton, taki co umie po polsku i po niemiecku.

- I pani też jest taką autochtonką?

- Tak" (WZ Siecioborzyce);

3. osobę miejscową:

"- Mówili o was autochtoni?

- To dobre określenie. Tak. (...) Autochton, to jest taki, który tutaj się urodzit i siedzi na swoim" (MK Dąbrówka Wlkp.).

"Autochtoni, tak nas nazwali zaraz po wojnie. To byli wszyscy co na tych terenach mieszkali" (SS Nowe Kramsko).

W wypowiedziach podkreślany jest fakt, że jest to nazwa nie pochodząca z ich języka, lecz nadana im z zewnątrz: „to tak jak urzędowo gdzieś to autochtoni mówili, ale potem to zanikało" (JW Podmokle Wielkie).

Odwołujemy się do kategorii człowieka pogranicza, jako zgodnej z antropologicznym podejściem i odpowiedniej nie tylko do opisu pogranicza terytorialnego (zewnętrznego), ale przede wszystkim mentalnego (psychologicznego, osobniczego, wewnętrznego) ${ }^{8}$.

Portret antropologiczny tworzymy z cech kulturowych wspólnych dla wszystkich rozmówców. Podstawą do wyodrębnienia głównych rysów portretu jest analiza narracji rozumianych jako „forma rozumienia świata i strukturalizacji doświadczenia ujmowanego w kategoriach ludzkich intencji" (W. Burszta 2004: 181). Do wywiadów w formie swobodnych rozmów o życiu skłoniło nas przekonanie, że dzięki nim „oddamy głos” naszym rozmówcom - ludziom pogranicza - nie zamykając ich w sztywnym schemacie ankiety. Podobnie jak inni badacze pograniczy, zauważyłyśmy, że bardziej skategoryzowane wywiady "zbytnio upraszczałyby tamtejszą skomplikowaną rzeczywistość" (Kłosek 2005: 24). W wielu przypadkach kontakt nie miał jednorazowego charakteru. Wracałyśmy do rozmówcy po dniu lub kilku dniach, niekiedy po kilku miesiącach, czasem wielokrotnie. Przyjęta metoda pozwalała dotrzeć do sposobu doświadczania świata przez rozmówcę, do subiektywnych sensów nadawanych ludziom, przedmiotom oraz dziejącym się wydarzeniom i otaczającym zjawiskom. Nie o wszystkim jednak świadkowie przeszłości chcą wspominać. Przemilczenia dotyczą wydarzeń, w których rozmówcy brali udział, a nie wpisują się one we współczesną ogólnonarodową narrację historyczną, lub z prze-

\section{-....}

8 Problem rozróżniania pogranicza terytorialnego (zewnętrznego) od mentalnego (wewnętrznego, osobniczego, psychologicznego) poruszają między innymi Antonina Kłoskowska (2005: 125), Ewa Nowicka (1999: 14), Elżbieta Smułkowa (2002: 483). Na personalny wymiar pogranicza zwracają uwagę Justyna Straczuk (2006: 256), Elżbieta Smułkowa (2007: 7), Anna Engelking (2008: 264). Omówienie prac dotyczących typów pogranicza znajduje się w artykule Anny Engelking, Ewy Golachowskiej, Anny Zielińskiej (2008: 15,16). 
życiami traumatycznymi, które wywołują bolesne wspomnienia. Z tego powodu są także niszczone dokumenty przeszłości, na przykład zdjęcia mężczyzn w mundurach Wehrmachtu. Zdjęcia rodzinne i listy z Niemiec bywały często przedmiotem zainteresowania Służby Bezpieczeństwa, ich posiadanie dla jednego z rozmówców zakończyło się aresztowaniem. Nachodzenie przez służby, rewizje, przesłuchania, propozycje współpracy w zamian za paszport dla członków rodziny to też tematy, które przewijały się w rozmowach z nami, przeważnie wspomniane, ale nie rozwijane. Niechętnie przywoływane są przykre wspomnienia. „Co się przeżyło to się nie mówi, pani. Dwa tygodnie świata nie widziałam, bo zamknięta tego, ojcowie mnie ukrywali" (RŻ Przyborze) opowiada rozmówczyni o sytuacji w momencie wkroczenia Armii Czerwonej, kiedy miała 18 lat. Rozmowy bywały dramatyczne, a wspomnienia do tej pory nieprzetworzone i nieprzepracowane $w$ ramach społecznego ustalania narracji wywoływały silne emocje, nawet płacz (na przykład relacja o zgwałceniu matki przez polskich żołnierzy w 1945 roku - w jakiej wspólnocie w Polsce mogtaby być opowiadana i do jakiej historii pasować? Jak wpisać to indywidualne doświadczenie w scenariusz panującej kultury?).

IDENTYFIKACJE ETNICZNE

Małgorzata Melchior proponuje rozróżnienie terminologiczne między „tożsamością" a „poczuciem tożsamości":

\begin{abstract}
„Mówiąc [...] o tożsamości jednostki (ale także i grupy), ma się zwykle na myśli jej sens niejako "obiektywny», "zobiektywizowany», czy też "zewnętrzny», to znaczy: pewien sposób postrzegania jednostki (lub grupy) przez innych, który stanowi próbę odpowiedzi na pytanie "kim ona jest». Terminu "poczucie tożsamości jednostki» (ale nie grupy) używa się natomiast w odniesieniu do subiektywnego sposobu postrzegania siebie przez jednostkę, gdy próbuje ona odpowiedzieć sobie na pytanie «kim ja jestem». Te dwa aspekty zagadnienia mogą być wyrażane przeciwstawieniem np. wewnętrznej i zewnętrznej tożsamości jednostki, subiektywnej i obiektywnej, przypisanej przez otoczenie społeczne i doświadczanej (lub konstruowanej) przez samą jednostkę" (1990: 24).
\end{abstract}

Tożsamość zewnętrzna naszych rozmówców, czyli przypisana przez innych, często jest odmienna od wewnętrznej, subiektywnej, odczuwanej i wyrażanej w narracjach; na przykład wspomniana wcześniej kategoria autochtona była konstruowana zewnętrznie z uwzględnieniem tylko polskich elementów kulturowych i całkowitym pominięciem związków z kulturą niemiecką. Niemiecką tożsamość przypisywali im osiedleńcy z różnych regionów Polski, przezywając ich "Niemcy”, „Hitlerowcy”, "Germany":

„W 1945 roku, jak jechałem wozem konnym, bo rodzice gospodarstwo rolne mieli, to mi mówili Heil Hitler" (JS Zabór).

„W tym czasie (bezpośrednio po wojnie - przyp. aut.) byliśmy Niemcami, tymi cholernymi Niemcami. Nie mieliśmy żadnego prawa" (ŁB Pszczew).

"moje dzieci (urodzone już w Polsce - przyp. aut.) to Niemcy i tak wytykali" (BC Zielona Góra) ${ }^{9}$.

9 Jednoznaczne przypisywanie niemieckiej narodowości rdzennym mieszkańcom jest obecne i dzisiaj, o czym miałyśmy okazję się przekonać przy poszukiwaniach rozmówców. Gdy wyjaśniałyśmy pracownikom różnych placówek kulturalnych (biblioteki, domy kultury), że poszukujemy osób urodzonych na miejscu przed wojną, zwykle kierowano nas do „Niemców” lub nawet doradzano nam kontakt z działaczami organizacji mniejszości niemieckiej. 
Tożsamość zewnętrzna, przypisywana, przyczyniała się do poczucia bycia w mniejszości. O swojej sytuacji w kontekście relacji społecznych mówią:

„W Niemczech - Polak, w Polsce - Szwab" (BC Zielona Góra).

„Minderheit - trzecia kategoria Niemców. Nas tak Niemcy nazywali. A Polacy nazywali nas autochtoni" (SS Nowe Kramsko).

"Moja siostra zawsze tak mówiła: jak ja chcę być Polką, to muszę do Niemiec jechać, to zawsze mówią: o, tamta Polka, a jak chcę być Niemką, to tu w Polsce: o, to ta Niemka" (MŁ Zielona Góra).

Tymczasem tożsamość wewnętrzną naszych rozmówców charakteryzuje polsko-niemiecka biwalencja kulturowa i nieopowiadanie się w sposób jednoznaczny za tylko jedną opcją narodową. W zebranych przez nas narracjach rzadkie są jednoznaczne deklaracje, takie jak w wypowiedziach rozmówcy ze Skwierzyny:

"Jestem Polakiem, dla mnie najważniejsze Bóg, honor, ojczyzna"; "Jestem wychowany na Sienkiewiczu"; "Służę Polsce, bo jestem Polakiem, patriotą"; "Moja babcia mówiła podczas okupacji w czterdziestym trzecim roku, nasza kochana święta Polska" (BR Skwierzyna).

Rozmówczyni z ziemi babimojskiej mówi natomiast:

"My są ludzie spod znaku rodła. Takie prawdziwe Polaki" i przywołuje sformułowanie, jakim pod koniec wojny określit jej postawę znajomy Niemiec: „fanatyczna Polka” (AC Nowe Kramsko).

Także innego typu wypowiedzi tej rozmówczyni potwierdzają znaczenie tego wymiaru identyfikacji. O jego wadze można wnioskować na przykład na podstawie wyrażanych opinii o Innych (sąsiadach, znajomych etc.):

„Nasz sołtys też był Polak, tak jak my, ale Niemca wielkiego udawał. On był za sołtysa. I ja mówia do matki (...): wszyscy ludzie idą po Bezugsschein ${ }^{10}$, to jo też pójdo, nie muszo iść, ale pójdo, choć kupio i komuś dom. Ja przyszła i tu było dwóch milicjantów, i taki Hilfspolizei"1, taki pomocniczy jeden był, i on był z Kargowy, tu dojeżdżał (...). I jak ja przyszła, zapukałam, weszłam i mówie Guten Abend ${ }^{12}$, dobry wieczór, a on mówi: Hinter Tür ${ }^{13}$, za drzwi. Ja wyszła, bo ja myśla ten milicjant tam jest, nie. A jak ja za te drzwi wyszła, to milicjant otwiera zaś drzwi, że mom przyjść, a on mówi do mnie: unser Gruß ist Heil Hitler, nasze pozdrowienie jest Heil Hitler. A ja mówia (...), że przecie ja pozdrowiła Guten Abend, a on mówit: unser Gruß ist Heil Hitler, a ja mówia, ja sram na wasz Bezugsschein (...)- ja będa i bez waszego Bezugsscheina w trzewikach chodzić. Zamkłam drzwi i poszłam" (AC Nowe Kramsko).

Wypowiedzi tego typu wyraźnie wskazują na wewnętrzne podziały w obrębie społeczności lokalnych z Babimojszczyzny zamieszkanych przez ludność pochodzenia polskiego. Stanowią one efekt wyborów identyfikacyjnych ich członków w zakresie przynależności do grupy etnicznej, przekładając się na ich behawioralny aspekt, tj. na zachowania w dziedzinie respektowania norm i wartości danej grupy (por. Machaj 2001: 86). Rozmówcy ze wsi, w których zamieszkiwała polska mniejszość w Niemczech, czyli z Nowego Kramska i Dąbrówki Wielkopolskiej, wspominają podział na rodziny, które posyłały dzieci po polskich szkół (mniejszościowe szkoły działały od 1929 do 1939 r.), i takie, które wybierały szkołę niemiecką. Wybór szkoły był zarazem wyborem opcji narodowościowej i języka domowego. W rodzinach, w których dzieci kształcity się w niemieckiej szkole zmieniano język na niemiecki. W ocenie rozmówczyni (AC Nowe Kramsko) był to bardzo słaby niemiecki, niską kompetencję językową tych osób ilustruje dowcip „Der Kur hat mir ganze

10 Niem. Bezugsschein 'talon'. Chodzi tu o talon, który w czasie Il wojny światowej uprawniał do zakupu butów.

11 Niem. Hilfspolizei 'policjant pomocniczy'.

12 Niem. Guten Abend 'dobry wieczór'.

13 Niem. Hinter Tür 'za drzwi'. 
oziminka ausgedreptet"14. Z relacji wynika, że w wyborze szkoły decydujący był czynnik ekonomiczny, ponieważ nauka dziecka w niemieckiej szkole przyczyniała się do wzrostu zamożności rodziny:

„- Były mieszane i też, jak myśmy określali, nasi Polacy popsuci. Bo oni przeszli na niemiecką strunę, dzieci wysyłali do niemieckiej szkoły.

- Kiedy oni przeszli?

- Za Hitlera, warunki materialne to sprawiły. Z miejsca dostali pracę, jak dzieci wysyłał do niemieckiej szkoły (....) to rodziny bogate w dzieci, kinderreiche Familie ${ }^{15}$. Mieli dużo dzieci i dzieci do niemieckiej szkoły. Także to byli właściwie Polacy, można powiedzieć, to nie byli czyści Niemcy. No ale nie można i tych ludzi krytykować (...) Jak ktoś miał warunki, i warunki pracy inne, materialne inne, a w Niemczech mieszkaliśmy siak czy tak. Czemu z tego nie korzystać, nie?" (MK Dąbrówka WIkp.).

Wybór polskiej szkoły łączył się z sankcjami ekonomicznymi, na przykład ojciec rozmówczyni z Nowego Kramska (AC) został pozbawiony renty. Był jednak zaangażowany w utrzymanie polskości i nie przepisał dzieci do szkoły niemieckiej (a rentę i tak po dwóch latach otrzymał). Kramszczanie mówili, że gdyby tak uczynił, zaginęłaby polskość w ich wsi:

„Żeby ojciec wziął nas trzy dzieci ze szkoły, to by się rozleciała szkoła, bo pojedynczo posyłali. (...) I sóm ten król polski mówit: Benysek, jak wy weźmiecie dzieci do niemieckiej szkoły, to polska szkoła się rozleci" (AC Nowe Kramsko).

O mieszkańcach Nowego Kramska, którzy wybrali opcję niemiecką opowiada:

„Tacy jak my. Wszystko Polaki tak jak my, ale niemiecką stronę trzymali. I to byli tacy. Bo oni na nas mówili Minderheiten ${ }^{16}$, to my byli tacy oddzieluni od nich - ani kąpać się nie chcieli (...) to jak kąpać się to: z Polakuma nie pójdema się kąpać, Polacy na lewo. Niemcy. Nimcy, tacy Nimcy jak my. Ale za Nimca uchodzili. (...) no, to to jacy oni teraz byli? Ani ni to Polak, ani ni to Niemiec. A po polsku, po niemiecku nie umieli, ino: vier Kuren, ein Kur drepten ${ }^{17}$. (...) I to tak się pomieszało, i to Kramsko podupadło. Bo tak jak Dąbrówka, to tam się Polska utrzymała i wszystko, i zabawy, i wszystko. A tu nie. Tu się tak zniemczyli pomału. I do Nimiec pouciekali do roboty, w świat" (AC Nowe Kramsko).

Kategoryzacje te wskazują na przekonanie, że można być „bliżej” lub „dalej” od symbolicznego centrum danej całości społecznej. Podział na Polaków i Niemców nie ma w tym wypadku dychotomicznego charakteru, lecz przeradza się w kontinuum. A zatem pomiędzy „prawdziwymi Polakami”, "twardymi Polakami” (przezywanymi w latach 30. i 40. "Minderheiten") a "czystymi Niemcami”, „prawdziwymi Niemcami”, „typowymi Niemcami” pojawiają się kategorie „renegatów” (por. Sauter 1961: 46-57; Benyskiewicz 1976: 41), „popsutych Polaków”, „przyszytych Niemców”18. Tak nazywane są osoby wywodzące się z polskich rodzin, ale z różnych względów niepodtrzymujące związków z polskością, tj. z kulturą i językiem polskim, z polskimi organizacjami i polską szkołą. Niekiedy ostentacyjnie deklarujące przynależność do świata niemieckiego ${ }^{19}$. Przynależność do grupy et-

\section{- • • •}

14 Niepoprawny niemiecki, w intencji autorki wypowiedzi 'kogut podeptał mi całą oziminkę'.

15 Niem. kinderreiche Familie 'rodzina wielodzietna'.

16 Niem: Minderheiten 'mniejszości'.

17 Niepoprawny niemiecki, ilustrujący niską kompetencję językową mówiących, prawdopodobnie: 'cztery kury, jeden kogut drepczą'.

18 Stopniowanie nazw narodowych w dyskursach styku/pogranicza kultur i narodów, w których łatwo dochodzi do konkurowania różnych tożsamości, zauważane jest także przez innych autorów, por. m.in. Stanisław Ossowski (1967).

19 Miałyśmy okazję przekonać się o obecności ostentacyjnego opowiadania się za niemieckością przy okazji rozmowy z trzema mieszkankami Nowego Kramska, z których dwie uczęszczały przed wojną do szkoły niemieckiej (GA, GB). Rozmówczynie te wygłaszały poglądy o wyższości kultury niemieckiej, przytaczając różne przykłady z życia codziennego i społecznego. Ukończoną przez nich szkołę niemiecką uważają także za o wiele lepszą niż polską. 
nicznej nabiera tym samym skalarnego charakteru, granice grupy stają się nieostre, ich kontury się rozmywają, o odrębności nie stanowią również kompetencje kulturowe członków zbiorowości, ponieważ te są zróżnicowane (por. przytoczoną relację z Nowego Kramska o posługiwaniu się niepoprawnym językiem niemieckim, por. Machaj 2001: 86). Zjawisko to można dostrzec również w autodeklaracjach niektórych osób niepochodzących z Babimojszczyzny, żyjących dalej od międzywojennej granicy polsko-niemieckiej:

"Jestem halb deutsch halb polnisch"20 (JR Białcz).

„Kiedyś ja szłam i oni mówią tak: ty nie jesteś Polka, ty jesteś Niemka: ja jestem Polka! Jak to

Polska, jestem Polka, Niemka jestem tylko połowa" (WZ Siecioborzyce).

Autorki tych wypowiedzi sytuują siebie w obrębie dwóch zbiorowości (podwójna przynależność). Sytuacja ta świadczy o przenikalności granicy rozdzielającej Polaków i Niemców. Problem skalarnego charakteru identyfikacji wiążącej się z przynależnością etniczną pojawia się również w stwierdzeniu: „ja się czuję stoprocentowo Polakiem” (BC Zielona Góra). Charakterystyczne w narracjach ludzi pogranicza polsko-niemieckiego jest nakładanie się kategorii z różnych porządków makrostrukturalnych, głównie narodowego i państwowego. Do rzadkości należy wypowiedź rozgraniczająca te dwa aspekty przynależności:

„Obywatel niemiecki, narodowość polska, tak mieliśmy w dowodach. Myśmy byli obywatelami niemieckimi" (MK Dąbrówka Wlkp.).

Zdecydowanie częściej pojawiają się stwierdzenia, w których przynależność do państwa i przynależność do narodu wyrażane są w jednakowy sposób:

„Po niemiecku nie umieli, ale byli Niemcami, bo w Niemczech" (AC Nowe Kramsko).

"Wszyscy byliśmy deutsch, Wehrmacht" (FN Dąbrówka Wlkp.).

"Myśmy byli Niemcami - reichsdeutsch"21 (ŁB Pszczew).

„Moja babcia (...) ona jechała tam (...) w osiemdziesiątych latach tamtego stulecia (XIX wieku

- przyp. aut.), ale już nie nauczyła się po niemiecku, a była z poznańskich stron. Babcia była

Niemką, bo to były protektorat, protektorat z niemieckim (...). Babcia była Niemką i nie umiała po niemiecku. I przez to moja mama jest Niemką, ale mama nauczyła się tam w Niemczech od swojej mamy".

„Nasi sąsiedzi to nie robili rozróżnienia, dla nich to my się tam urodzili, to byliśmy normalnymi tam Niemcami" (BC Zielona Góra).

Utożsamianie kategorii etnicznych i wyznaniowych obecne jest w wywiadach osób z Babimojszczyzny. Przynależność konfesyjna i etniczna używane są zamiennie lub jako porządki dopełniające się:

"- A ewangelicy czasem chodzili do waszego kościoła, albo wy do nich, czy to wszystko tak oddzielnie?

- Nie, nie. Niemiec trzymał swoje, Niemcy trzymały swoje" (AC Nowe Kramsko).

"- A Rogoziniec już byli Niemcy, po prostu ileś nie wiedziałam, dlaczego w Rogozińcu byli wyłącznie ewangelicy. Bo już wioska Chociszewo, było niemieckie, ale katolicy. Ksiądz katolicki przyjeżdżał i dalej, i Lutol i Bukowiec, to wszystko byli katolicy, tu Kosieczyn katolicy.

- Ale Niemcy?

- Tak. Lutol Suchy. I tak samo Szczaniec (...) katolicki był. I jak było pięćdziesięciolecie technikum obchodzone w Rogozińcu, to taka książeczka była wydana i tam któraś pani doszukała się w historii, że była taka plaga, że powiem, ludzie wszyscy w Rogozińcu wymarli i wtedy Niemcy sprowadzili samych ewangelików i też kościół ewangelicki wybudowali. Wykorzystali to i [osiedlili] Niemców. Nam nawet nie wolno było do kościoła iść, to jest niemieckie, ewangelickie, tam się nie chodzi" (MK Dąbrówka Wlkp.).

20 Niem. 'pół Niemca, pół Polaka'.

21 Niem. reichsdeutsch 'Niemiec, obywatel Rzeszy'. 
Wspomniane nakładanie porządków nie ma jednak charakteru totalnego. Niekiedy jest to jedynie zazębianie się, pozwalające na skalarne doświadczanie dystansu pomiędzy „mną" a przedstawicielem obcej grupy. W ten sposób na przykład rozróżnia się „typowych”, „prawdziwych”, „czystych” Niemców, tj. ewangelików, od bardziej swojskich Niemców - członków Kościoła rzymskokatolickiego.

Po 1945 roku jednoznaczna deklaracja przynależności do narodu polskiego stanowiła podstawę decyzji komisji weryfikacyjnej rozstrzygającej o możliwości pozostania w państwie polskim. W tym samym czasie podejmowane były działania na rzecz upodobnienia się do zbiorowego stereotypu Polaka. Należą do nich między innymi nauka ogólnego wariantu języka polskiego, zmiana imion i nazwisk, które w kontekście kultury polskiej miały obce brzmienie (por. Nitschke 2006: 282):

„Potem w Polsce już w 1945 roku jak się zapisałam to zamiast Margit od razu tą polską wersję pisałam: Małgorzata. (...). To była moja osobista decyzja. (...) Chciałam w Polsce, żeby nie mieć trudności" (MŁ Zielona Góra).

Z perspektywy lat niektórzy rozmówcy postrzegają te działania w negatywnym świetle. Rodzi to ich sprzeciw wobec potrzeby poczucia ciągłości tożsamości22:

„Nie trzeba zmieniać nazwiska. (...) Szczerze pani powiem, ja jednego nie rozumiem. (...), w miejscu, gdzie się urodziłem mam nazwisko na przykład Hugo. W metryce urodzenia niemieckiej Hugo pisze. To powinienem się w dalszym ciągu Hugo pisać. Nie popolszczyć. Na przykład, jak miałem Jerzy, miałem Georg, zrobili Jerzy. To mi się nie podoba. Bo metrykę urodzenia wyciągnął i pisze [w niej]: Georg. A pisze się znowu [teraz] Jerzy. Tak samo ten książę, ten syn tej cesarzowej. Hans-Georg. To będzie Jerzy. I czasem ktoś to mówi: co to za jeden? Po polsku Jerzy pisze, nie wszyscy, ale piszą Jerzy. Powinno się tak pisać, jak w metryce urodzenia. Cały czas. Tak myślę ja" (JS Zabór).

Podobne działania podejmowane były wcześniej, przed i podczas wojny. Wiązały się z procesami nabywania kompetencji kulturowych właściwych względem ówczesnych cech miejsca zamieszkania (np. przyjmowanie języka niemieckiego we wsiach należących do polskiej enklawy w Niemczech), przy jednoczesnym nieeksponowaniu cech do niego nienależących. Dzisiaj rozmówcy używają dwóch wersji imion: niemieckiej w kontaktach z Niemcami i polskiej w kontaktach z Polakami. W ten sposób funkcjonują dublety: Bruno i Bronisław, Elisabeth i Elżbieta, Hanni i Janina, Lothar i Lutek itp. Niektórzy zachowali do dzisiaj w dokumentach niemiecki zapis imienia (np. Johanna, Lothar, Vera) oraz nazwiska:

"To bezwzględnie czy to będzie Rosja, czy to będzie Niemcy, tak litera w literę, tak ma być pisane. I mówię [do urzędnika]: pan musi pisać ei i dwa n, koniec" (JW Podmokle).

W refleksji nad własnym życiem pojawiają się pytania dotyczące dokonanych przed laty wyborów identyfikacyjnych. Rozmówcy - nawet ci wywodzący się z rodzin "twardych Polaków" - nie przejawiają zdecydowanych postaw narodowych, wykazując się pragmatyzmem myślenia. Jedna z mieszkanek ziemi babimojskiej - przedwojenna harcerka z rodziny o silnej orientacji propolskiej, uczennica polskiej szkoły mniejszościowej- mówi: „a jak by do lagru brali, to pierwszą by mnie wzięli. Po co mi to było?" (AC Nowe Kramsko). Porównując warunki życia w Polsce i w Niemczech, ta sama rozmówczyni mówi:

"Ci Polacy są nic nie warci. Jak Pan Bóg ludzi chce ukarać, to Polaka do rządu dopuści" (AC Nowe Kramsko).

Ważne jest tu rozróżnienie dwóch immanentnych aspektów tożsamości: kontynuacji i identyczności (sameness), a z drugiej strony odrębności i granicy (distinctiveness). Pierwszy z nich skupia się na problemie utrzymania ciągłości (pozostawanie tym samym), podczas gdy drugi podkreśla kwestię odróżniania się danego podmiotu od innych (ja a inni) (Bokszański 2006: 37). 
W identyfikacjach naszych rozmówców odnaleźć można różne wymiary kategoryzowania świata społecznego, klasyfikowania ludzi na "swoich" i "obcych" (w tym wspomniane zasady przynależności i podobieństwa, odwołujące się do różnych poziomów życia społecznego - tak makrostrukturalnego, jak i regionalnego, i lokalnego). Wybory identyfikacyjne przez nich dokonywane wynikają z różnorodnych uwarunkowań i mają zazwyczaj kontekstualny charakter. "Ona taka, ona była raz Polka, raz Niemka, raz volksdeutsch, ona tak" (JW Skwierzyna) - opowiada o swojej przybranej matce jedna z rozmówczyń. Szczególnie w przeszłości deklaracja w dziedzinie etniczności miała decydujące znaczenie dla losów jednostki i rodziny. Przynależność narodowa - należąca do poziomu makrostrukturalnego - mocno zaznacza się w codziennym życiu naszych rozmówców, w ich interakcjach na poziomie lokalnym. Widać to zwłaszcza w wypowiedziach mężczyzn o ich wojennych i powojennych losach; najstarsi byli żołnierzami Wehrmachtu, młodsi urodzeni w latach 30. i 40. podlegali obowiązkowej służbie wojskowej w PRL. Podczas służby wojskowej byli traktowani z dużą podejrzliwością, poddawani różnym procedurom sprawdzającym ich lojalność państwową, przesłuchaniom i inwigilacji. Ich kariera na niektórych stanowiskach pracy (np. jeden z rozmówców był szewcem produkującym buty wojskowe) wiązała się zwykle z koniecznością zatajania pochodzenia lub podawania fałszywych danych.

BIWALENCJA KULTUROWA

Z ekologicznym wymiarem identyfikacji wiąże się fakt zamieszkiwania na obszarze pogranicza polsko-niemieckiego. Bliskość granicy pomiędzy światem polskim a niemieckim (w sensie państwowym i kulturowo-społecznym), jej doświadczanie w życiu codziennym - w interakcjach społecznych i percypowanej przestrzeni - ma swoje odniesienie również w świadomościowym wymiarze funkcjonowania jednostki. Ludzi pogranicza polsko-niemieckiego cechuje biwalencja kulturowa, są dwujęzyczni, egzystują w kręgu kultury polskiej i niemieckiej. W tym kontekście pojawia się inny aspekt identyfikacji - problem zajmowanej pozycji w ramach stratyfikacyjnego wymiaru struktury społecznej. Dwujęzyczność i kontakt z kulturą niemiecką stanowią zazwyczaj możliwość podwyższenia swojego statusu ekonomicznego, są źródłem prestiżu, pozycji w strukturze społeczności lokalnej, a również dowartościowania we własnych oczach. Stopień zachowania języka niemieckiego: zakres jego używania oraz kompetencje są zróżnicowane, ale związki emocjonalne z tym językiem są na ogół bardzo silne. Antonina Kłoskowska pisze, że własną kulture się zna i przeżywa na poziomie emocji (2005: 110-111), a zatem można uznać, że język niemiecki jest częścią własnej, przeżywanej, przyswojonej w dzieciństwie kultury. W wywiadach wyrażana jest duma ze znajomości języka niemieckiego i kontaktów z Niemcami. Emocje uwidaczniają się w deklaracjach doskonałej znajomości języka (zwykle mówią, że niemiecki znają „perfekt”"23 albo „korrekt”24), potwierdzanej opowiadaniami o zdziwieniu, jaką budzi ich sprawność językowa wśród Niemców:

„W zeszłym roku parę razy jako tłumaczka jechałam do Niemiec z jednym gospodarzem, który tam kupowat rolnicze sprzęty no i nie znat niemieckiego, więc miałam okazję pojechać raniutko no i w nocy wracać, (...) sobie do tej nędznej renty dorobić, nie. No i po prostu to była taka moja satysfakcja, że mogłam kogoś pomóc. A tam jak my zajechali, każdy najpierw się pytat,

23 Niem. 'znakomicie'.

24 Niem. 'poprawnie'. 
a skąd umiem tak niemiecki. To od urodzenia, prawda jak się mówi. I to mnie potem też trochę cieszyło, że mogłam komuś pomóc" (ŁB Pszczew).

Zdarza się, że swoją kompetencję w języku niemieckim oceniają wyżej niż w polskim:

„Po polsku pisać mi jest niedobrze, nie potrafię do dzisiaj, tylko po niemiecku piszę. Nie napiszę [po polsku], bo ja się nie interesuję. Jakbym się interesowała, no to bym pisała, mnie to nie interesuje, mnie to nie obchodzi, ja pisze po niemiecku. Zakupy robić, to ja po niemiecku piszę sobie" (WZ Siecioborzyce).

Rozmówczynie z Białcza regularnie przyjmują w swoich domach gości z Niemiec. Podczas rozmowy prezentują zeszyty z wpisami (zatytułowane: Gästebuch ${ }^{25}$ ), liczne listy z podziękowaniami, okazjonalne pocztówki z życzeniami (wyeksponowane w salonie). Podkreślają swoje więzi emocjonalne z przybywającymi regularnie byłymi mieszkańcami ich miejscowości (chociaż same nie pochodzą z Białcza, tylko z Bredow-Luch ${ }^{26}$ ). Rdzenni mieszkańcy w swoich wspólnotach lokalnych pełnią funkcję nieformalnych lub nawet zawodowych tłumaczy27 i przewodników dla gości z Niemiec. Tylko rozmówczyni z Nowego Kramska negatywnie odnosi się do swojej niemczyzny; obecny przy rozmowie syn informuje nas, że matka „po niemiecku lepiej pisze aniżeli po polsku”, co wywołuje jej protest:

„A, g...o umiem. Po niemiecku jo już nic nie umio. Błędów od kaduka i nazad. Bo to a kropkowane i o kropkowane, e, idź ty cholero! Stary człowiek jest nic nie warty" (AC Nowe Kramsko).

Mieszkańcy Nowego Kramska i Dąbrówki Wlkp., którzy przed 1945 rokiem w domach zachowali polszczyznę, też musieli znać niemiecki:

„Siłą rzeczy, nie, no musieliśmy się uczyć niemieckiego. No i na ulicy, czy nawet po zakupy, jak się szło do sklepu, trzeba było tylko mówić po niemiecku. (...) A nic w czasie wojny nie można było kupić, tylko dla poszkodowanych od bomb było wszystko. Albo na Bezugsschein, na jakieś kwity, dowody. Poszłam do urzędu gospodarczego, bo był taki i tam pani wypisała, że mogę kupić szczoteczkę do zębów. (...) ale to jest też i dowód, że ja musiałam w miarę mówić po niemiecku, bo tak bym się nie dogadała" (MK Dąbrówka Wlkp.).

Polszczyzna, którą mówiono w tych wsiach należy do dialektu wielkopolskiego, nazywana jest „językiem krumskim, mową krumska" - w Nowym Kramsku oraz "językiem dąbrowieckim, mową dąbrowiecką" - w Dąbrówce Wlkp. Gwara przeciwstawiana jest polszczyźnie ogólnej, nazywanej „językiem pańskim” lub „polskim prawdziwym”:

„Dużo tych określeń naszych dąbrowieckich było nietypowych, nie. Albo takich bardzo staropolskich, na przykład filiżanka, nikt u nas nie mówił filiżanki, tylko poćki, od picia, albo kapołka, serwotka, od kapania takie, atrament, inkaust. Tak mówili. Po wojnie trzeba było się uczyć prawdziwego polskiego. Może tam jeszcze teraz różnie gadamy" (MK Dąbrówka Wlkp.).

W Pszczewie, który w Niemczech był skupiskiem polskiej mniejszości ${ }^{28}$, nie było polskiej szkoły. W rodzinach rozmówczyń dokonała się zmiana języka z polskiego na niemiecki na początku lat 30. Do 1945 roku nie znały polskiego, nie licząc kilku gwarowych słów:

"- Pani ojciec skąd pochodzit?

- Z Poznańskiego, i wszyscy bardzo dobrze mówili po polsku, rodzice i cała rodzina, tyle że potem już nie wolno było mówić po polsku, jak Hitler do władzy doszedł.

- Jak pani się urodziła w 30 . roku, to już był koniec?

25 Niem. Gästebuch 'książka pamiątkowa dla gości'.

26 Wieś Bredow-Luch leżała pod Berlinem. Z relacji wynika, że do 1945 roku znajdowała się tam kolonia osadników z Polski.

27 Pomagają swoim sąsiadom m.in. w staraniach o odszkodowania dla przymusowych robotników w III Rzeszy, tłumacząc potrzebne dokumenty.

28 Patrz: prace Zygmunta Dulczewskiego (1961, 1971). 
- Tak, ale moje starsze rodzeństwo, na przykład mój brat najlepiej jeszcze umiał po polsku, bo we wojnie był tłumaczem też. Jak na Polskę szli i w Rosji, także on miał dużo styczności z Polakami i lubiał bardzo po polsku mówić (...). Ja nie umiałam, no tak od babci parę słów, liczyć, co krzesło, to kiedyś stołek moja babcia mówiła, na wiadro wimborek, to pamiętam parę stów, taka gwara poznańska" (ŁB Pszczew).

Podobna sytuacja była $w$ innych rodzinach, które mieszkały poza Babimojszczyzną: w latach 30. już mówiono w domach po niemiecku. W rodzinach katolickich wywodzących się z Poznańskiego, najstarsi jeszcze używali polskiej gwary. Inaczej było w rodzinach ewangelickich, od pokoleń tylko niemieckojęzycznych. Po 1945 wszyscy musieli zacząć mówić po polsku:

„(W jakim języku mówiła Pani w domu rodzinnym? Po niemiecku, czy po polsku?) To zależy jaki czas już był. Jak za niemiecki, to my po niemiecku rozmawiali, a później to już po polsku" (EM Nowy Kisielin); „Do szkoły się chodziło niemieckiej, to się mówiło po niemiecku. No jak można było inaczej? A już po wojnie trza było język przerobić" (RŻ Przyborze).

O problemach z przyswojeniem polszczyzny przez przedwojennych mieszkańców Pszczewa świadczy relacja o przebiegu uroczystego aktu wręczania dokumentu stwierdzającego tymczasowe polskie obywatelstwo:

"- To były nasze pierwsze dokumenty. Przynależność do, autochtony to dostali. (...) to były nasze pierwsze papiery, muszeliśmy się jeszcze jak ruski byli, czy Polacy już, się zameldować i potem szkolili nas, jak dostaniemy to wręczone, to żeby dziękuję powiedzieć, jestem Polakiem (śmiech).

- (Po polsku powiedzieć?)

- No tak po polsku, ja to umiałam, ale tak wszyscy (śmiech)" (ŁB Pszczew).

Języka polskiego uczyli się w szkole lub na specjalnych kursach dla dorosłych:

„W 47 roku został dla nas autochtonów tu organizowany kurs języka polskiego i też kurs dla Polaków, którzy w czasie wojny nie mogli chodzić do szkoły, mieli możność kończyć tutaj, razem w tym czasie siódmą klasę. Ale mało chodziło, bo to jednak trudno było nawet autochtony, te starsze osoby nie dały radę, albo zniechęceni byli, bo nie dali rady w szkole, aj pamiętam ja, nie chcę się chwalić, ale w tej klasie ja prawie że najlepiej znałam język polski. (...) Nauczycielka była ze wschodu, też ten akcent miała, za bardzo dobrze też nie umiała, z książki uczyła nas" (ŁB Pszczew).

Niektórzy podejmowali próby przekazywania języka niemieckiego swoim dzieciom i wnukom po 1945 roku, m.in. rozmówczyni z Siecioborzyc nauczyła biegle mówić po niemiecku swojego wnuka, dzieci rozmówczyni z Zielonej Góry nauczyły się niemieckiego od jej matki, która nie przyswoiła sobie polskiego. Używanie języka niemieckiego nawet w kręgu rodzinnym było niebezpieczne, w latach powojennych groziło represjami, łącznie z wysiedleniem:

„My już tam mieszkaliśmy i przyjechali [osadnicy] ze Wschodu. Było takie małżeństwo, że im się bardzo spodobało nasze gospodarstwo. A przecież wiedzieli, że my mówili po niemiecku, że to, że tamto, że nie udzielamy się tu tak bardzo. Trochę byliśmy osobno i oni donieśli na policję i jeszcze tam gdzieś. I przyjechała policja wieczorem (...), to było w 46 roku, przy końcu. I dokumenty tatowy wszystkie tam (...), i mówią, że będą nas wysiedlać. A tato patrzy i mówi: Mnie? Na pewno, nie" (WJ Białcz).

Polszczyzna nasycona niemieckimi interferencjami, którą posługiwali się rozmówcy, funkcjonowała jak goffmanowskie piętno ${ }^{29}$. Język (odmienny od polszczyzny przesied-

-....

29 „Gdy ktoś, kto w zwykłych interakcjach [...] mógtby zostać bez trudu zaakceptowany, zostaje nosicielem łatwo zauważalnej, odstręczającej nas od niego cechy, okoliczność ta zarazem deprecjonuje inne jego właściwości, które mogłyby wywrzeć na nas pozytywne wrażenie. Taką osobę obciąża piętno, zasadniczo modyfikujące nasze antycypacje w stosunku do niej" (Goffman 2005: 35). 
leńców z różnych obszarów Polski) stygmatyzował swoich użytkowników jako wrogów - Niemców i czynił z nich ofiary odwetu za cierpienia Polaków w czasie II wojny światowej. Społeczna akceptacja normy odpowiedzialności zbiorowej ${ }^{30}$ pozwalała na przemoc w szkole w stosunku do dzieci, które dopiero zaczęły uczyć się polskiego lub znały z domu lokalny wariant języka nasycony germanizmami. Z relacji o przeżyciach w szkole najbardziej drastyczna dotyczyła fizycznej przemocy wobec 7-letniego chłopca przez nauczyciela. Wspominane są szykany i przezwiska ze strony innych uczniów. Strach, upokorzenie były tak silne, że niektórzy porzucali szkołę i kształcili się na kursach dla dorosłych:

„Do szóstej klasy niemiecki. Jak Polska tu nastała, to ja myślałem, że będzie dobrze (...) o rany, co myśmy tu przeżyli, myśmy mówili po polsku, ale nie czysto, zatrącaliśmy i tak dalej, to i Niemcami nas, ci koledzy, uczniowie, i Niemcy, i Szwaby, i Hitlerowcy, ja się biłem z nimi: Ja nie jestem Hitlerowcem, ja jestem Polakiem, i tak dalej. No i nie mogliśmy wytrzymać" (BR Skwierzyna).

"Dlatego że macocha głupia wysłała mnie do szóstej klasy polskiej. A ja ni be ni ce nie umiem, wiecie co, tak się ze mnie śmieli wszyscy. I więcej nie poszłam do tej szkoły. Co ta macocha, do szóstej klasy, jak ja do niemieckiej [szkoły chodziłam]" (JW Skwierzyna).

W konstruowaniu tożsamości rozmówców ważny jest ich kontakt z co najmniej dwoma wyznaniami: katolickim i ewangelickim. Uczestnictwo w kulturze pogranicza, której cechą immanentną jest wielowyznaniowość, jest stopniowalne i kontekstualne; są osoby dwuwyznaniowe oraz takie, które pozostając w kręgu jednej tradycji, znają i rozumieją wyznawców innych religii lub przynajmniej mają na ich temat jakąś wiedze (por. Straczuk $2006,10)$. W wywiadach z mieszkańcami ziemi babimojskiej można zauważyć znany badaczom polskiego wschodniego pogranicza „swoisty „wzór kulturowy pogranicza« z naczelną normą, głoszącą, że nie ma wiar lepszych i gorszych, ale że każda jest najlepsza dla jej własnych wyznawców" (Engelking 2011, w druku). Postrzeganie wyznań w kategoriach konstatacji a nie oceny, równorzędności a nie hierarchii jest charakterystyczne dla tradycyjnych społeczności pogranicza, ukształtowanych w wielopokoleniowej koegzystencji (por. Engelking 2011, w druku). O braku negatywnego wartościowania innego wyznania świadczą wypowiedzi katoliczek:

"Byli dobrzy [ewangelicy], nie byli kiepscy. Tak zgodnie żyli" (RŻ Przyborze).

"To Jehowa, ale porządni ludzie są bardzo" (AC Nowe Kramsko).

Podkreślana jest wspólnotowość, to co łączy, a nie oddziela: „jeden Pan Bóg”; „Wszyscy równy pacierz mówimy" (AC Nowe Kramsko). Wśród rozmówców mieszkających we wsiach na ziemi babimojskiej, które przed II wojną światową stanowiły polskie enklawy, nie spotyka się dwuwyznaniowości i konwersji religijnych. Zjawiska te są obecne w życiu rozmówców spoza enklawy (por. Zielińska, w druku). Z ich punktu widzenia wyznanie nie stanowi różnicy kulturowej ważnej w codziennym doświadczeniu i nie tworzy opozycji swój-obcy. W niektórych rodzinach konwersje są dokonywane w kilku pokoleniach, zwykle przyczyną było zawieranie konfesyjnie mieszanych małżeństw. Na przykład: ojciec rozmówczyni z Zielonej Góry (MŁ) zmienił wyznanie z katolickiego na ewangelickie; ona ochrzciła dzieci w Kościele ewangelickim, ale syn przed ślubem z katoliczką przeszedł do Kościoła katolickiego. Rozmówczyni traktuje konwersję syna jako jego osobisty wybór niepodlegający ocenie. W dalszej części wywiadu wręcz podkreśla, że konwersje w rodzinie przyczyniają się do lepszego porozumiewania się osób różnych wyznań, opowiadając

\section{......}

30 Zbigniew Czarnuch pisze o stosowaniu zasady zbiorowej odpowiedzialności i ideologii odwetu na terenach inkorporowanych w 1945 roku. Zemsta obejmowała wszystko co materialne i niematerialne, a było naznaczone piętnem niemieckiego pochodzenia (2010). 
o przyjacielskich relacjach z sąsiadką katoliczką: „Ona właśnie nie jest taka zawzięta, jest praktykująca, owszem, ale jej ojciec był ewangelikiem i może ona dlatego". Rozmówcy często nie dostrzegają istotnych różnic między wyznaniem katolickim i ewangelickim. Powtarza się stwierdzenie, że „to to samo”, „nie ma różnicy”, a te różnice, które są dostrzegane, interpretowane są jako nieznaczące. Nierozróżnialność umożliwia uczestniczyć katolikom w nabożeństwie w kościele ewangelickim:

"Ewangelicka wiara się niczym innym nie różni, że oni tylko w Matkę Boskie nie wierzą". "Ja byłam w Łodzi na kursie, to tam najbliżej miałam do ewangelickiego kościoła, to tam chodziłam parę razy. To muszę pani powiedzieć, że kazania też ściśle na temat ewangelii. A u nas są kazania, o, niektórzy to mają na temat ewangelii, a niektórzy to mają takie kazania, że to mózg w poprzek" (MT Dąbrowa).

Rozmówczyni z Siecioborzyc, wychowana w rodzinie ewangelickiej, uczestniczy w liturgii trzech wyznań chrześcijańskich: katolickiego, ewangelickiego i zielonoświątkowego (dzieci dokonały konwersji i należą do Kościoła Zielonoświątkowego). Opowieść o swojej uwspólniającej trzy wyznania religijności podsumowuje stwierdzeniami: „do Boga trzeba, bo jak nie..."; "Bóg jest jeden, nie ma dziesięciu Bogów”. Nierozróżnialność widoczna jest także w sferze języka religii: „Nie ma różnicy, słowa są przetłumaczone te same: Vater unser, der Du bist im Himmel, Ojcze nasz, który jesteś w Niebie, to to samo" (BR Skwierzyna). Charakterystyczny dla badanej kategorii ludzi pogranicza polsko-niemieckiego jest brak wartościowania wyznania i języka, nie ma różnic w prestiżu języka religii, nie ma języka bardziej godnego i mniej godnego do obsługiwania sfery sacrum.

Ważnym elementem kategoryzowania świata społecznego przez naszych rozmówców są uniwersalne wartości. Przebiegają one ponad identyfikacjami opartymi na przynależności. Ich podstawą jest identyfikacja budowana na zasadzie podobieństwa/odmienności według uniwersalistycznych, ponadetnicznych i ogólnoludzkich cech (dobrzy/źli ludzie, przyzwoici/nieprzyzwoici, pracowici/leniwi, uczynni/egoistyczni etc.). Za egzemplifikację mogą posłużyć takie wypowiedzi jak poniższa:

„paskudy wszędzie się trafią, w każdym kraju" (JS Zabór).

„Wszędzie są ludzie złe i dobre, jak mówią, o verfluchter ${ }^{31}$ Niemiec, albo verfluchter Polak, nie, wszędzie jednakowe. (...) Jesteśmy wszyscy tylko ludźmi" (JR Białcz).

"Teraz to ty jesteś taki, ty jesteś taki, nikt nie zwracał uwagi na to, czy ten taki, czy ten taki. To głupota jest, że ten jest taki, ten jest taki, bo każdy jest człowiek" (MT Dąbrowa).

Rozmówcy reprezentują otwarty typ pogranicza mentalnego. Mimo złych doświadczeń w latach powojennych odnoszą się z empatią do swoich sąsiadów z grup osiedleńców (współczują np. Kresowianom, którzy stracili swoje domy). Ze swojego zakorzenienia i dwukulturowości czynią sens swojego istnienia. Czują się "strażnikami pamięci”, co wyraża się w działaniach na rzecz zachowania pamięci społecznej, a wśród nich współpracę z dawnymi i obecnymi mieszkańcami na rzecz upamiętnienia historycznych wydarzeń, które rozegrały się w przestrzeni lokalnej, uchronienia przed zapomnieniem ważnych postaci związanych z danym miejscem. Działania tego typu można zinterpretować jako wyraz potrzeby poczucia ciągłości całego świata lokalnego. Ich egzemplifikacją mogą być: ufundowanie tablicy pamiątkowej w Przytoku z napisem "minęło już tyle lat, chcemy zapomnieć co kiedyś było, chcemy zawsze tylko na przód patrzeć, wspólne nowe przyszłość wspólną budować"32; kolekcjonowanie pamiątek związanych z pałacem w Zabo-

31 Niem. 'przeklęty'.

32 Tekst napisu na tablicy przytoczony przez rozmówczynię (EM) z Nowego Kisielina inicjatorki jej postawienia. 
rze i jego dawną właścicielką cesarzową Herminą; zbieranie zdjęć architektury Landsberga; oddawanie pamiątek zaświadczających o przeszłości do izby pamięci w Babimoście; prowadzenie kroniki lokalnej Dąbrówki Wlkp.; edukacja młodszego pokolenia w zakresie tradycji lokalnej, współpraca z zespołem folklorystycznym w Nowym Kramsku i w Pszczewie; wydanie skróconej wersji pamiętników ojca ${ }^{33}$. Dwukulturowość, a zwłaszcza znajomość języka niemieckiego, czyni z nich tłumaczy, przewodników i pośredników w kontaktach między dawnymi i nowymi mieszkańcami regionu. Zbigniew Czarnuch nazywa ich "ludźmi pomostami", a ich domy "samozwańczymi konsulatami”, wskazując na ważną rolę, jaką odgrywają w przygranicznym regionie ${ }^{34}$. Żaden z naszych rozmówców nie żałuje, że został w Polsce.

\section{LISTA ROZMÓWCÓW35}

AC Nowe Kramsko: 1922 Neu Kramzig (Nowe Kramsko)

AJ Kruszyna: 1938 Schwarmitz (Swarzynice)

AJ Nowa Sól: 1924 Damerau (Dąbrowa)

BC Zielona Góra: 1929 Niederlausitz (Dolne Łużyce), wywiad przeprowadzony przez Martynę Netzel BR Skwierzyna: 1933 Schwerin an der Warthe (Skwierzyna)

EM Nowy Kisielin: 1916 Polnisch Kessel (Stary Kisielin)

EP Nowa Sól: 1930 Külpenau (Kiełpin), wywiad przeprowadzony przez Wiktorię Czepułkowską

FN Dąbrówka Wielkopolska: 1924 Groß Dammer (Dąbrówka Wielkopolska)

GA Nowe Kramsko: ok. 1924 Neu Kramzig (Nowe Kramsko)

GB Nowe Kramsko: ok. 1924 Neu Kramzig (Nowe Kramsko)

HT Dąbrowa: 1942 Damerau (Dąbrowa)

JR Białcz: 1929 Bredow-Luch

JR Podmokle Mate: 1930 Klein Posemuckel (Podmokle Mate)

JS Zabór: 1928 Saabor (Zabór)

JW Skwierzyna: 1932 Schwerin an der Warthe (Skwierzyna)

JW Podmokle Wielkie: 1928 Groß Posemuckel (Podmokle Wielkie), wywiad przeprowadzony przez

Elżbietę Janowską

ŁB Pszczew: 1930 Betsche (Pszczew)

LC Gorzów Wlkp.: 1944 Landsberg (Gorzów Wlkp.)

MK Dąbrówka WIkp.:1931 Groß Dammer (Dąbrówka Wlkp.)

MŁ Zielona Góra: 1924 Grünberg in Schlesien (Zielona Góra), wywiad przeprowadzony przez Monikę Kowalińską i Magdalenę Kozłowską

MT Dąbrowa: 1934 Damerau (Dąbrowa)

MW Przylep: 1935 Grünberg in Schlesien (Zielona Góra), wywiad przeprowadzony przez Monikę Kowalińską i Magdalenę Kozłowską

RŻ Przyborze: 1927 Neudorf (Przyborze)

SS Nowe Kramsko: 1930 Neu Kramzig (Nowe Kramsko)

33 Stróżczyńska, Stróżczyńska-Wille 2004.

34 Rozmowa autorek ze Zbigniewem Czarnuchem w lutym 2010 r. w Witnicy. Mgr Zbigniew Czarnuch mieszka od 1945 r. w Witnicy, jest osiedleńcem z ziemi wieluńskiej. Nauczyciel, historyk, regionalista, inicjator i organizator spotkań dawnych i obecnych mieszkańców gminy Witnica (m.in. był inicjatorem Polsko-Niemieckiego Stowarzyszenia „Pro Europa Viadrina”). Działa na rzecz ochrony i upamiętniania dziedzictwa kulturowego w regionie. Propaguje otwartość i humanistyczną, empatyczną postawę w stosunku do wygnanych ze swoich domów Niemców - byłych mieszkańców pogranicza. Przeciwdziała zachowaniom ksenofobicznym, piętnuje zasadę odpowiedzialności zbiorowej za zbrodnie wojenne w stosunku do wszystkich Niemców (por. Czarnuch 2010).

35 Podajemy inicjał i miejsce zamieszkania, a dalej rok i miejsce urodzenia. 
WJ Białcz: 1929 Bredow-Luch

WJ Nowe Kramsko: 1939 Neu Kramzig (Nowe Kramsko)

WS Pszczew: 1930 Betsche (Pszczew)

WZ Siecioborzyce: 1932 Tempelburg (Czaplinek)

\section{LITERATURA}

Benyskiewicz Joachim (1976), Nowe Kramsko. Studium polityczno-gospodarcze, wyd. Lubuskie Towarzystwo Naukowe, Zielona Góra.

Benyskiewicz Joachim, 1994, Babimojszczyzna 1919-1945, Zielona Góra: Wydawnictwo "Rodło".

Bokszański Zbigniew, 2006, Tożsamości zbiorowe, Warszawa: Wydawnictwo Naukowe PWN.

Burszta Józef, 1967, Kategorie ludności i ich typ kulturowy, [w:] Markiewicz Władysław, Rybicki Paweł (red.), Przemiany społeczne na Ziemiach Zachodnich, Poznań: Instytut Zachodni, s. 132-177.

Burszta Józef, 1971, Wieś lubuska. Na podstawie badań wsi Głuchowo i Łegowo, [w:] Dulczewski Zygmunt (red.), Społeczeństwo Ziem Zachodnich. Studium porównawcze wyników badań socjologicznych w województwie zielonogórskim w latach 1958-1960 i 1968-1970, Poznań: Instytut Zachodni, s. 105-149.

Burszta Józef, 1974a, Tradycje kultur regionalnych w osadnictwie wiejskim na ziemiach województw zachodnich, [w:] Józef Burszta, Szkice i rozprawy. Kultura ludowa - kultura narodowa, Ludowa Spółdzielnia Wydawnicza, s. 96-131.

Burszta Józef, 1974b, Tradycje regionalne w procesie integracji kulturowej wsi, [w:] Józef Burszta, Szkice i rozprawy. Kultura ludowa - kultura narodowa, Ludowa Spółdzielnia Wydawnicza, s.132-154.

Burszta Wojciech, 2004, Różnorodność i tożsamość. Antropologia jako kulturowa refleksyjność, Poznań: Wydawnictwo Poznańskie.

Czarnuch Zbigniew, 2004, Na tropie tożsamości Ziemi Torzymskiej, [w:] Toczewski Andrzej (red.) Ziemia Lubuska. Studia nad tożsamością regionu, Zielona Góra: Muzeum Ziemi Lubuskiej, Towarzystwo Przyjaciół Muzeum Ziemi Lubuskiej w Zielonej Górze s. 71-97.

Czarnuch Zbigniew, 2010, Niemieckie dziedzictwo kulturowe $w$ recepcji polskich osadników rejonu ujścia Warty. Relacje i refleksje świadka epoki, [w:] Mykietów Bogusław, Tureczek Marceli (red.), Władza i społeczeństwo wobec niemieckiej spuścizny kulturowej na Ziemi Lubuskiej po /l wojnie światowej, Zielona Góra: Arcanum, s. 11-41.

Ćwiklińska Emilia (red.), 1995, Wiestaw Sauter. W 90. rocznice urodzin, Zielona Góra: Lubuskie Towarzystwo Naukowe.

Dokowicz Maria, Sidło Aniela Anna, Nowak Gerard (red.), 1998, Lubuski Zespół Pieśni i Tańca, Zielona Góra: Regionalne Centrum Animacji Kultury.

Dulczewski Zygmunt, 1961, Autochtonizacja ludności na Ziemiach Zachodnich. Fragment badań w miejscowości Pszczew, pow. międzyrzecki, [w:] Dulczewski Zygmunt (red.), Tworzenie się nowego społeczeństwa na Ziemiach Zachodnich. Szkice i materiały z badań socjologicznych w województwie zielonogórskim, Poznań: Instytut Zachodni, s. 13-67.

Dulczewski Zygmunt, 1962, Regionalizm lubuski, "Nadodrze”, nr 5. 
Dulczewski Zygmunt, 1967, Tworzenie się nowych spoteczności regionalnych na Ziemiach Zachodnich, [w:] Markiewicz Władysław, Rybicki Paweł (red.), Przemiany spoteczne na Ziemiach Zachodnich, Poznań: Instytut Zachodni, s. 313-337.

Dulczewski Zygmunt, 1971, Pszczew. Procesy autochtonizacji ludności, [w:] Dulczewski Zygmunt (red.), Społeczeństwo Ziem Zachodnich. Studium porównawcze wyników badań socjologicznych w województwie zielonogórskim w latach 1958-1960 i 1968-1970, Poznań: Instytut Zachodni, s. 29-104.

Engelking Anna, 2008, Kim jest „człowiek pogranicza”? Uwagi o tożsamości z perspektywy badacza i z perspektywy podmiotu - przykład białoruski, [w:] Engelking Anna, Golachowska Ewa, Zielińska Anna (red), Tożsamość - Język - Rodzina. Z badań na pograniczu słowiańsko-bałtyckim, Warszawa: Slawistyczny Ośrodek Wydawniczy, s. 247-266.

Engelking Anna, 2011, Białoruska wieża Babel, czyli mityczne uzasadnienie tożsamości religijnej na pograniczu wyznaniowym. Wersja kotchoźników z Grodzieńszczyzny, [w:] Golachowska Ewa, Zielińska Anna (red.), Wokót religii i jej języka. Konstrukcje i destrukcje tożsamości, Warszawa: Slawistyczny Ośrodek Wydawniczy, w druku.

Engelking Anna, Golachowska Ewa, Zielińska Anna, 2008, Tożsamość, język i pamięć w sytuacji pogranicza. Uwagi wprowadzające, [w:] Engelking Anna, Golachowska Ewa, Zielińska Anna (red), Tożsamość - Język - Rodzina. Z badań na pograniczu słowiańskobałtyckim, Warszawa: Slawistyczny Ośrodek Wydawniczy, s. 7-24.

Glapa Adam, 1956, Strój babimojsko-międzyrzecki (lubuski), Lublin: Polskie Towarzystwo Ludoznawcze.

Goffman Erving, 2005, Piętno. Rozważania o zranionej tożsamości. Przekład Aleksandra Dzierżyńska, Joanna Tokarska-Bakir, Gdańsk: Gdańskie Wydawnictwo Psychologiczne.

Gołdyka Leszek, 2003, Teraźniejszość i przyszłość pogranicza polsko-niemieckiego w aspekcie socjologicznym, [w:] Polska - Niemcy. Dziś i jutro. Polen - Deutschland. Heute und Morgen, Warszawa: Wyd. Pagina, s. 281-304.

Kłosek Eugeniusz 2005, Świadomość etniczna i kultura społeczności polskiej we wsiach Bukowiny rumuńskiej, Wrocław: Wyd. Uniwersytet Wrocławski.

Kłoskowska Antonina 2005, Kultury narodowe u korzeni, Warszawa: Wydawnictwo Naukowe PWN.

Kołodziejska Barbara, 2006, Ludowe dziedzictwo pokoleniowe we współczesnej kulturze Środkowego Nadodrza, "Rocznik Lubuski”, t. 32.

Koniusz Janusz, 1978, O początkach regionalnej działalności kulturalnej i naukowej na Środkowym Nadodrzu, "Rocznik Lubuski” t. 10.

Kościk Zbigniew, 2005, Polski Związek Zachodni wobec autochtonów na Ziemi Lubuskiej w latach 1945-1950, [w:] Osękowski Czesław (red.), Z dziejów Ziemi Lubuskiej po drugiej wojnie światowej, t. 1, Zielona Góra: wyd. Uniwersytet Zielonogórski, s. 89-109.

Kurcz Zbigniew, 1999, Pogranicze polsko-niemieckie a "polnische Wirtschaft”, [w:] Gołdyka Leszek (red.), Transgraniczność w perspektywie socjologicznej - kontynuacje, Zielona Góra: Lubuskie Towarzystwo Naukowe, Wyższa Szkoła Pedagogiczna im. T. Kotarbińskiego w Zielonej Górze, s. 219-234.

Kutrzebianka Anna, 1950, Lud i jego zwyczaje (etnografia), [w:] Sczaniecki Michat, Zajchowska Stanisława (red.), Ziemia Lubuska, Poznań: Instytut Zachodni, s. 167-190.

Machaj Irena, 2001, Kategorie odmienności i przynależności w pojmowaniu siebie i $w$ definiowaniu innych na obszarach pogranicza, [w:] Leszkowicz-Baczyński Jerzy (red.), Transgraniczność w perspektywie socjologicznej. Kontynuacje i wyzwania, ZieIona Góra: Lubuskie Towarzystwo Naukowe, s. 81-94. 
Melchior Małgorzata, 1990, Społeczna tożsamość jednostki (w świetle wywiadów z Polakami pochodzenia żydowskiego urodzonymi w latach 1944-1955), Warszawa: Uniwersytet Warszawski, Instytut Stosowanych Nauk Społecznych.

Mucha Janusz, 2001, Polskie pogranicze zachodnie a tworzenie sie "nowej kultury", [w:] Leszkowicz-Baczyński Jerzy (red.), Transgraniczność w perspektywie socjologicznej. Kontynuacje i wyzwania, t. II, Zielona Góra: Lubuskie Towarzystwo Naukowe, Uniwersytet Zielonogórski, s. 71-96.

Nitschke Bernadetta, 2006, Repolonizacja czy polonizacja? Polityka władz polskich wobec byłych kresów wschodnich III Rzeszy, [w:] Wyder Grażyna, Nodzyński Tomasz (red.), Polacy i Niemcy. Pogranicze. Studia historyczne, Zielona Góra: wyd. Uniwersytet Zielonogórski, s. 275-290.

Nowicka Ewa, 1999, Badanie pogranicza. Kilka propozycji metodologicznych, [w:] Sadowski Andrzej (red.) Pogranicze. Studia społeczne, tom 8, Białystok: Wydawnictwo Uniwersytetu w Białymstoku., s. 13-22.

Ossowski Stanisław, 1967, Więź narodowa i więź regionalna na Górnym Śląsku, [w:] Dzieła, t. 3, Warszawa: Państwowe Wydawnictwo Naukowe, s. 251-300.

Ossowski Stanisław, 1984, O ojczyźnie i narodzie, Warszawa: Państwowe Wydawnictwo Naukowe.

Pokrzyńska Magdalena, Zielińska Anna, 2010, Człowiek pogranicza polsko-niemieckiego. W świetle wywiadów antropologicznych, [w:] Skorupska-Raczyńska Elżbieta, Rutkowska Joanna (red.), Dziedzictwo kulturowe regionu pogranicza, tom III, Gorzów Wielkopolski: Państwowa Wyższa Szkoła Zawodowa w Gorzowie Wielkopolskim, s. 247-262.

Rutowska Maria, Tomczak Maria, 2003, Ziemia Lubuska jako region kulturowy, Poznań: Instytut Zachodni.

Sauter Wiesław, 1961, Powrót na Ziemie Piastowskie, Poznań: Wydawnictwo Poznańskie. Sczaniecki Michat, Zajchowska Stanisława (red.), 1950, Ziemia Lubuska, Poznań: Instytut Zachodni.

Smułkowa Elżbieta, 2002, Kształt wspótistnienia na polsko-białorusko-litewskim pograniczu językowym, [w:] Smułkowa Elżbieta (red.), Białoruś i pogranicza. Studia o języku i spoteczeństwie, Warszawa: Wydawnictwo Uniwersytetu Warszawskiego, s. 483-491.

Smułkowa Elżbieta, 2007, Wokół pojęcia pogranicza. Wschodnie i zachodnie pogranicze Białorusi w ujęciu porównawczym, [w:] Smułkowa Elżbieta, Engelking Anna (red.), Pogranicza Białorusi w perspektywie interdyscyplinarnej, Warszawa: Wydawnictwo DiG, s. 5-14.

Straczuk Justyna, 2006, Cmentarz i stót. Pogranicze prawosławno-katolickie w Polsce i na Białorusi. Wrocław: Wydawnictwo Uniwersytetu Wrocławskiego.

Stróżczyńska Wanda, Stróżczyńska-Wille Ewa, 2004, Dawno temu w Pszczewie. Wspomnienia spisane przez Franciszka Golza i innych świadków epoki, Gorzów Wlkp.: Wyd. Arsenat.

Wysiedlenia, 2008, Wysiedlenia, wypędzenia i ucieczki 1939-1959, Atlas ziem Polski, Sienkiewicz Witold, Hryciuk Grzegorz (red.), Warszawa: Demart S.A.

Zielińska Anna, w druku, Sytuacyjność, przechodniość, nierozróżnialność w sferze życia religijnego jako cechy kultury pogranicza polsko-niemieckiego (na przykładzie badań terenowych na ziemi lubuskiej), [w:] Cyran Grzegorz, Skorupska-Raczyńska Elżbieta (red.) Język doświadczenia religijnego t. IV, Państwowa Wyższa Szkoła Zawodowa w Gorzowie Wielkopolskim, Uniwersytet Szczeciński, Wydział Teologiczny. 


\section{AN ANTHROPOLOGICAL PORTRAYAL OF THE NATIVE INHABITANTS OF THE POLISH-GERMAN BORDERLAND BORN BEFORE 1945}

\section{Summary}

The article presents the results of field research carried out among the native inhabitants of the Lubusz Voivodship who were born in the former eastern territory of the then German state before 1945. Between 2009 and 2011, the authors conducted in-depth anthropological interviews with 28 informants in 17 localities in the Voivodship. These informants are the last remaining representatives of the former populace in this area, since the majority of the local inhabitants left Poland: some were evacuated or fled in the face of the advancing Red Army in 1945, some were victims of the so-called "wild" expulsions, as well as resettlements and a policy of bringing families together. One more factor was an economic emigration, which has continued up to the present day. Thus, those inhabitants who remained are the last witnesses to the history of life experiences which began here already in pre-World War II times. This makes them special and their status has a unique sense of rootedness in the region, unlike other inhabitants, who are newcomers here.

The external identity of the interviewees, that is the identity given to them by others, is often different from their internal, subjective identity, which is felt and expressed in narratives. In the period following World War II the native populace was termed "autochtons." The category of "autochton" was constructed from the outside, taking into consideration only elements of Polish culture, and completely ignored any ties with German culture. The presence of the "autochtons" officially served the purpose of legitimizing the so-called "recovered territories," that is the territories incorporated into Poland in 1945. On the other hand, the autochtons were ascribed a German identity by new settlers who arrived in the Lubusz land from different regions of Poland, and who labeled the locals "Germans," "Nazis," "Germany." The internal identity of the interviewees is characterized by Polish-German cultural biwalence, which shows most of all in their active bilingualism and often in denominational conversions or bivalent (catholic-evangelical) faith as well as a lack of a univocal acceptance of just one national option.

Keywords: native inhabitants, the Polish-German borderland, internal identity, external identity 